\title{
Role of leptin receptors in granulosa cells during ovulation
}

\author{
Lisa Dupuis, Yasmin Schuermann, Tamara Cohen, Dayananda Siddappa, Anitha Kalaiselvanraja, \\ Melissa Pansera, Vilceu Bordignon and Raj Duggavathi
}

Department of Animal Science, McGill University, Sainte Anne de Bellevue, Quebec, Canada H9X 3V9

Correspondence should be addressed to R Duggavathi; Email: raj.duggavathi@mcgill.ca

\begin{abstract}
Leptin is an important hormone influencing reproductive function. However, the mechanisms underpinning the role of leptin in the regulation of reproduction remain to be completely deciphered. In this study, our objective is to understand the mechanisms regulating the expression of leptin receptor (Lepr) and its role in ovarian granulosa cells during ovulation. First, granulosa cells were collected from superovulated mice to profile mRNA expression of Lepr isoforms (LeprA and LeprB) throughout follicular development. Expression of LeprA and LeprB was dramatically induced in the granulosa cells of ovulating follicles at $4 \mathrm{~h}$ after human chorionic gonadotropin (hCG) treatment. Relative abundance of both mRNA and protein of CCAAT/enhancer-binding protein $\beta$ (Cebp $\beta$ ) increased in granulosa cells from 1 to $7 \mathrm{~h}$ post-hCG. Furthermore, chromatin immunoprecipitation assay confirmed the recruitment of Cebp $\beta$ to Lepr promoter. Thus, hCG-induced transcription of Lepr appears to be regulated by Cebp $\beta$, which led us to hypothesise that Lepr may play a role during ovulation. To test this hypothesis, we used a recently developed pegylated superactive mouse leptin antagonist (PEG-SMLA) to inhibit Lepr signalling during ovulation. I.p. administration of PEG-SMLA $(10 \mu \mathrm{g} / \mathrm{g})$ to superovulated mice reduced ovulation rate by $65 \%$ compared with control treatment. Although the maturation stage of the ovulated oocytes remained unaltered, ovulation genes Ptgs 2 and Has2 were downregulated in PEG-SMLA-treated mice compared with control mice. These results demonstrate that Lepr is dramatically induced in the granulosa cells of ovulating follicles and this induction of Lepr expression requires the transcription factor Cebp $\beta$. Lepr plays a critical role in the process of ovulation by regulating, at least in part, the expression of the important genes involved in the preovulatory maturation of follicles.

Reproduction (2014) 147 221-229
\end{abstract}

\section{Introduction}

Leptin, a hormone of adipose tissue origin, is primarily responsible for regulating energy and food intake. However, there is also clear evidence of its role in reproduction (Barash et al. 1996, Wauters et al. 2000). There are multiple isoforms of the leptin receptor (Lepr, A-F), of which LeprA (short isoform) and LeprB (long isoform) are known to transduce leptin signals in multiple cell types (Lee et al. 1996, Murakami et al. 1997). Although there has been significant progress in our understanding of the mechanisms of Lepr signalling in the hypothalamus, such clearer understanding is still lacking at the level of the ovary, specifically in granulosa cells.

Majority of studies examining direct effects of leptin on the ovary and granulosa cells have been in vitro, of which very few have addressed multiple Lepr isoforms. Expression of Lepr (mainly LeprB) has been demonstrated in the granulosa cells of many species including the mouse (Ryan et al. 2002), pig (Ruiz-Cortes et al. 2003), cattle (Spicer \& Francisco 1997) and human (Karlsson et al. 1997), clearly suggesting a direct effect of leptin on these cells. Expression of LeprA and LeprB was shown to be induced by preovulatory LH stimulus in rat ovaries (Ryan et al. 2003), although it was not measured in pure population of granulosa and luteal cells. Though numerous studies demonstrate the expression of Lepr in granulosa cells, none have addressed the mechanisms of regulation of Lepr expression. Potential transcription factors that could regulate Lepr expression in ovulating follicles include nuclear receptor 5a2 (Nr5a2; Duggavathi et al. 2008), progesterone receptor (Pgr; Lydon et al. 1995) and CCAAT/enhancer-binding protein $\beta$ (Cebp $\beta$; Sterneck et al. 1997), as they all play an indispensable role in ovulation. Further, it was recently reported that Lepr mRNA abundance was reduced in conditional knockout mice lacking Cebp $\alpha / \beta$ in granulosa cells (Fan et al. 2011). However, whether Cebp $\beta$ plays a role in Lepr expression in granulosa cells has not been investigated.

Regarding the role of Lepr in granulosa cells, the available data from in vitro studies have revealed contradicting results. Most studies have focused on their role in steroidogenesis of granulosa cells. In the rat and bovine, leptin was shown to suppress oestradiol $\left(E_{2}\right)$ production (Zachow \& Magoffin 1997, 
Spicer \& Francisco 1997, Duggal et al. 2000), whereas in the rabbit it showed augmented $E_{2}$ production (Sirotkin et al. 2009). Leptin was shown (Accili et al. 1996) to have suppressive effects on progesterone synthesis in bovine granulosa cells (Spicer \& Francisco 1997, Spicer 2001, Sirotkin et al. 2009); whereas dose-dependent bimodal effects were demonstrated in porcine granulosa cells (Ruiz-Cortes et al. 2003). Reported variations on the effect of leptin on granulosa cells appear to be due to wide range of dose of leptin $(1-100 \mathrm{ng} / \mathrm{ml})$ used in different studies. Although in vitro approach allows for investigation of direct effects, it is not suitable for testing the role of Lepr in processes like follicular rupture, cumulus expansion and corpus luteum $(\mathrm{CL})$ formation.

Data on mRNA expression in rat ovaries (Ryan et al. 2003) indicate that Lepr may be important for ovulation and/or luteinisation. Indeed, leptin is known to increase the expression of prostaglandin-endoperoxide synthase 2 (Ptgs2) in multiple cell types in vitro (Gao et al. 2009, Hsu et al. 2012, Manuel-Apolinar et al. 2013). However, direct effects of leptin, examined using superovulation models, on ovulation are also confusing with studies showing both reduced and increased number of ovulations in the rat (Almog et al. 2001, Ricci et al. 2006). This may be because of the number and dosage of leptin used in the treatments (Di Yorio et al. 2013). Thus, an alternative approach to study leptin signalling in granulosa cells would be to investigate the importance of Lepr expression in granulosa cells. Therefore, the objectives of our study were i) to examine pattern and regulation of the expression of LeprA and LeprB in granulosa cells during follicular and luteal development and ii) to examine the importance of Lepr expression in granulosa cells during ovulation.

\section{Materials and methods \\ Animal model}

All experimental protocols were approved by the Animal Care and Use Committee of McGill University. The inbred C57BL/6NCrl mice (Charles River, Senneville, QC, Canada) were housed in standard plastic rodent cages and maintained on a $12 \mathrm{~h}$ light: $12 \mathrm{~h}$ darkness cycle with ad libitum feed (Rodent Diet, Harlan Teklad, Montreal, QC, Canada) and water.

\section{Superovulation and sample collection}

Immature (23-25 days old) female mice were superovulated by administration of equine chorionic gonadotropin (eCG, 5 IU, i.p.) followed $48 \mathrm{~h}$ later by human chorionic gonadotropin (hCG, 5 IU, i.p.) (Duggavathi et al. 2008). Animals were killed at specific time points during the gonadotropin-stimulated follicular and luteal development. Pure populations of granulosa cells were collected by laser microdissection (Duggavathi et al. 2008) for initial profiling of genes of leptin signalling system. For further experiments involving the periovulatory period, granulosa cells were collected by follicular puncture using 27G needle. The cell suspension was passed through a cell strainer (BD Falcon, Mississauga, ON, Canada; $40 \mu \mathrm{m}$ ) to filter out cumulus-oocyte complexes. Granulosa cells from both ovaries of each mouse were pooled together. For luteal cell collection, $\mathrm{CL}$ from both ovaries were scraped off with a 27G needle and collected in PBS. All samples were stored at $-80^{\circ} \mathrm{C}$ until further analyses.

\section{Inhibition of leptin signalling}

A recently developed pegylated superactive mouse leptin antagonist (PEG-SMLA; mutant D23L/L39A/D40A/F41A; PLR Laboratories, Rehovot, Israel), which has been shown to inhibit leptin signalling (Shpilman et al. 2011), was used in this study. In line with hCG-induced Lepr expression in the granulosa cells of ovulating follicles, we administered PEG-SMLA (10 $\mu \mathrm{g} / \mathrm{g}$ body weight, i.p.) into eCG-primed mice at the time of hCG stimulation. Control mice were treated with PBS.

\section{Evaluation of ovulation rate and oocyte maturation}

Animals were killed at $18 \mathrm{~h}$ post-hCG to collect oviducts. The cumulus-oocyte complexes were collected and the cumulus cells were removed by a brief exposure to hyaluronidase $(1 \mathrm{mg} / \mathrm{ml})$. Oocytes were counted for ovulation rate and fixed in paraformaldehyde in PBS for $12 \mathrm{~min}$ at room temperature. They were then placed in PBS with $1 \%$ BSA in four-well plates and stored at $4{ }^{\circ} \mathrm{C}$. The following day, the oocytes were placed on slides with moviol and Hoechst 33342 stain $(10 \mu \mathrm{g} / \mathrm{ml})$ and observed under a stereomicroscope. The presence of a polar body and condensed chromosomes aligned on the metaphase plate indicated that the oocytes had progressed to the mature metaphase II stage (Mandelbaum 2000).

\section{Relative mRNA expression by quantitative PCR}

All quantitative PCR (qPCR) procedures were carried out in accordance with MIQE guidelines (Bustin et al. 2009). Total RNA was extracted from granulosa and luteal cells using the PicoPure RNA isolation Kit (Life Technologies, Burlington, ON, Canada). Using $250 \mathrm{ng}$ of total RNA, cDNA was synthesised using the iScript cDNA Synthesis Kit (Bio-Rad). Diluted (1:40) cDNA was subsequently used in qPCR analyses to determine mRNA levels. Primer sequences and efficiency of amplification for each set of validated primers are presented in Table 1. The qPCR was carried out with the following conditions: an initial denaturation at $95{ }^{\circ} \mathrm{C}$ for 5 min followed by 39 cycles at $95{ }^{\circ} \mathrm{C}$ for $15 \mathrm{~s}$ and $58{ }^{\circ} \mathrm{C}$ for $30 \mathrm{~s}$ for annealing, and $95^{\circ} \mathrm{C}$ for $10 \mathrm{~s}$. Relative mRNA expression data was analysed using the standard curve method. Data were normalised to the expression levels of two reference genes (B2m and Sdha) determined in each sample.

\section{Protein extraction and immunoblot analyses}

Following isolation of granulosa and luteal cells, $100 \mu \mathrm{l}$ of lysis buffer (Laemmli, PBS, 2-mercaptoethanol) was added to each sample with $1 \mu \mathrm{l}$ of each protease inhibitor: Mammalian 
Table 1 Primers used in real-time PCR studies.

\begin{tabular}{|c|c|c|c|}
\hline Gene & Forward primer & Reverse primer & $\begin{array}{l}\text { Amplification } \\
\text { efficiency }(\%)\end{array}$ \\
\hline LeprA & ACGCAGGGCTGTATGTCATT & САСТGАTTСТGСАTGСТTGG & 100 \\
\hline LeprB & CAAACCCCAAGAATTGTTCCTGG & TCAGGCTCCAGAAGAAGAGGACC & 90 \\
\hline Lep & GAGACCCCTGTGTCGGTTC & CTGCGTGTGTGAAATGTCATTG & 98 \\
\hline Сebp $\beta$ & GCAAGAGCCGCGACAAG & GGCTCGGGCAGCTGCTT & 99 \\
\hline Has2 & TGTGAGAGGTTTCTATGTGTCCT & ACCGTACAGTCCAAATGAGAAGT & 100 \\
\hline Ptgs2 & TGAGCAACTATTCCAAACCAGC & GCACGTAGTCTTCGATCACTATC & 99 \\
\hline Tnfaip6 & GGGATTCAAGAACGGGATCTTT & TCAAATTCACATACGGCCTTGG & 99 \\
\hline Lepr (ChIP) & GGCCTTCCTAGGAGAACGA & САAАATGTGАСТСАСТСАТСТG & 99 \\
\hline Myod1 (ChIP) & СССАGGACACGАСТGСТTTC & GGTTCTGTGGGTTGGAATGC & 93 \\
\hline Sdha & GGAACACTCCAAAAACAGACCT & ССАССАСТGGGTATTGAGTAGAA & 95 \\
\hline$B 2 m$ & TTCTGGTGCTTGTCTCACTGA & CAGTA GTTCGGCTTCCCATTC & 100 \\
\hline
\end{tabular}

Protease Arrest, Phosphatase Arrest III and EDTA (G Biosciences, St. Louis, MO, USA). The granulosa cell protein extracts were boiled at $95^{\circ} \mathrm{C}$ for $10 \mathrm{~min}$ and were stored at $-20^{\circ} \mathrm{C}$ until immunoblot analysis.

Proteins were separated by electrophoresis using 10\% SDS-PAGE gel, followed by transfer to nitrocellulose membrane. The membrane was blocked in 5\% milk in Tris-buffered saline with $0.1 \%$ Tween-20 (TBS-T) for $45 \mathrm{~min}$ at room temperature, followed by overnight incubation at $4{ }^{\circ} \mathrm{C}$ with a primary antibody, mouse monoclonal anti-mouse Cebp $\beta(1 \mathrm{H} 7)$ (1:2000, Abcam, Toronto, ON, Canada; cat no. ab15050). Following a TBST wash three times for $10 \mathrm{~min}$, the membrane was incubated with horse anti-mouse $(1: 10000$, Cell Signalling, Danvers, MA, USA; cat no. 7076) secondary antibody for $1 \mathrm{~h}$ at room temperature. The proteins were detected by Immun-Star Western Chemi luminescent Kit (Bio-Rad). The membrane was exposed using the gel imaging ChemiDoc XRS + System (Bio-Rad). Densitometry analyses of images were performed using Image Lab Software (Bio-Rad), in which protein quantification was done by comparison of CEBP $\beta$ protein isoforms relative to $\beta$-actin (Actb). Each of the five sets of immunoblots included samples from 0, 1, 4, 7 and $18 \mathrm{~h}$ post-hCG. Abundance of CEPBP was then normalised to hCG $0 \mathrm{~h}$ time point.

\section{Comparative bioinformatics analysis of Lepr promoter}

For comparative bioinformatic analysis, the Lepr promoter sequences of the mouse, human and rat were retrieved from UCSC Genome Browser. The genome assemblies from which the sequences obtained were Dec 2011 (GRCm38/mm10), Feb 2009 (GRCh37/hg19) and Nov 2004 (Baylor3.4/rn4) for mouse, human and rat respectively. The Lepr promoters analysed included sequences from $-2000 \mathrm{bp}$ to $5^{\prime}$-UTR. Sequences of each species were uploaded to online Patch Software (http://www.gene-regulation.com/cgi-bin/pub/programs/patch/bin/patch.cgi). The presence of putative Cebp $\beta$ binding sites was determined using the following settings: minimum length, 6; maximum mismatches, 1; mismatch penalty, 100 and lower score boundary, 87.5. The sequence of first 124 bases of $5^{\prime}$-UTR of Myod 1 was also analysed for the presence of $\operatorname{Cebp} \beta$ binding sites and this region was used as a negative control for chromatin immunoprecipitation (ChIP) analysis (described below).

\section{Chromatin immunoprecipitation}

ChIP analyses were performed as described previously (Duggavathi et al. 2008, Svotelis et al. 2011). Briefly, granulosa cells were crosslinked with $1 \%$ formaldehyde in PBS for 10 min at room temperature. The cells were then washed in PBS, resuspended in $200 \mu \mathrm{l}$ of ChIP lysis buffer (1\% SDS, $10 \mathrm{~mm}$ EDTA, $50 \mathrm{~mm}$ Tris- $\mathrm{HCl}(\mathrm{pH} 8.0)$ and protease inhibitors) and sonicated to obtain chromatin fragments of 200-500 bp. The chromatin solution was diluted tenfold in ChIP dilution buffer and $5 \%$ of the diluted lysate was used for purification of total DNA (as input). The chromatin was precleared by incubating with $2 \mu \mathrm{g}$ of salmon sperm DNA/protein A-agarose $50 \%$ gel slurry (Roche Diagnostics) for $2 \mathrm{~h}$ at $4{ }^{\circ} \mathrm{C}$. Then the chromatin was divided into two parts and each part was incubated with Cebp $\beta$ antibody (ab32358) or normal rabbit IgG at $4{ }^{\circ} \mathrm{C}$ overnight. Next morning, DNA-protein crosslinks were reversed by incubating at $65{ }^{\circ} \mathrm{C}$ overnight followed by proteinase $\mathrm{K}$ treatment. DNA was purified with the QIAquick PCR purification column (Qiagen). QPCR was carried out with primers for positive (Lepr) and negative (Myod1) loci. Amplicon abundance was expressed as the percent of immunoprecipitated DNA relative to the input DNA.

\section{Statistical analyses}

Analyses were performed using SigmaPlot 12.3 Software, San Jose, CA, U.S.A. Significant differences between time points for relative mRNA expression data were analysed by one-way ANOVA followed by Tukey's multiple comparisons post-hoc test. Relative levels of protein were analysed by one-way ANOVA followed by Fisher's least significant difference (LSD) multiple comparisons post-hoc test. Ovulation data, ChIP data and mRNA data from PEG-SMLA experiment were analysed by unpaired Student's $t$-test. Normality of data was confirmed by Shapiro-Wilk test. All data are expressed as mean \pm s.E.M. A significance level of $P<0.05$ was used.

\section{Results}

\section{Expression profiles of LeprA, LeprB and Lep}

In order to understand the regulatory mechanisms of Lepr signalling, we first profiled the expression patterns of its isoforms in purified granulosa and luteal cells 


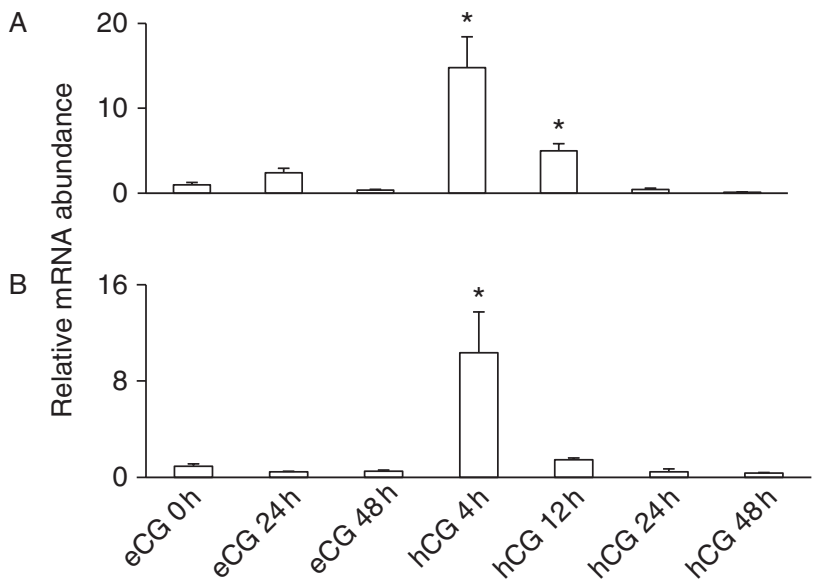

Figure 1 Relative mRNA abundance of LeprA (A) and LeprB (B) in granulosa and luteal cells isolated from ovaries collected at specific time points of the superovulation protocol. Average of mRNA abundance of reference genes $B 2 m$ and $S d h a$ was used to normalise the expression data. Data are expressed as mean \pm s.E.M. $(n=4-5$ per time point). ${ }^{*} P<0.05$.

during gonadotropin-induced follicular and luteal development. Of the six known isoforms, we examined the expression profile of the two isoforms that have been shown to transduce leptin signal, LeprA and LeprB (Baumann et al. 1996, Murakami et al. 1997). Relative levels of LeprA mRNA were low in granulosa cells from eCG-stimulated growing follicles. Their levels increased dramatically from $48 \mathrm{~h}$ post-eCG to $4 \mathrm{~h}$ post-hCG $(P<0.01)$ and declined by $12 \mathrm{~h}$ post-hCG $(P<0.01)$ followed by low levels through luteal phase (Fig. 1A). Relative mRNA levels of $L$ eprB were also low during the follicular phase and increased at $4 \mathrm{~h}$ post-hCG $(P<0.01)$, before declining to basal levels by $12 \mathrm{~h}$ post-hCG (Fig. 1B). Although LeprA and LeprB were both induced by hCG treatment, there were differences in the levels of their induction. LeprA expression was induced by a 23 -fold increase, whereas LeprB by a 11-fold increase from eCG 0 to $4 \mathrm{~h}$ post-hCG. At $12 \mathrm{~h}$ post-hCG, LeprA mRNA levels were still tenfold higher relative to $0 \mathrm{~h}$ eCG. However, LeprB abundance at $12 \mathrm{~h}$ post-hCG was similar to the basal level at eCG $0 \mathrm{~h}$. Taken together, these data indicate that mRNA abundance of LeprA was higher than LeprB in the granulosa cells of ovulating follicles ( 4 and $12 \mathrm{~h}$ post-hCG).

\section{Regulation of Lepr expression: role of Cebp $\beta$}

As both isoforms of Lepr were dramatically upregulated during the periovulatory period and $\operatorname{Cebp} \beta$ has been shown to regulate ovulatory events (Sterneck et al. 1997), we hypothesised that $\operatorname{Cebp} \beta$ may regulate $L e p r$ transcription. This hypothesis was tested using multiple approaches. First, comparative bioinformatics analyses of proximal promoters of the mouse, human and rat Lepr genes showed multiple potential binding sites for $\operatorname{Cebp} \beta$ (Fig. 2). Specifically for the mouse promoter, this analysis identified three potential Cebp $\beta$ binding sites at -537 , -579 and -1620 from transcription start site. Second, expression profile of $C e b p \beta$ in purified granulosa and luteal cells showed that the mRNA abundance significantly increased in granulosa cells during periovulatory period. Maximal expression occurred at $1 \mathrm{~h}$ post-hCG, with a significantly higher expression during the period of $1-7 \mathrm{~h}$ post-hCG compared with other time points $(P<0.001$; Fig. 3A). Third, we examined the protein levels of Cebp $\beta$ isoforms in the granulosa cells of periovulatory follicles. Cebp $\beta$ is expressed as three isoforms generated by differential initiation of translation (Cottrell \& Mercer 2012), namely, a full-length isoform, a LAP (liver-enriched activator protein) isoform and a truncated LIP (liver-enriched inhibitory protein) isoform (Calkhoven et al. 2000). As LAP and LIP isoforms have been shown to have transcriptional activity (Descombes \& Schibler 1991), we quantified their abundance. In line with the mRNA expression profile, the protein abundance of LAP ( 4 and $7 \mathrm{~h}$ post-hCG) and LIP (7 h post-hCG) isoforms was higher in periovulatory granulosa cells relative to granulosa cells at hCG-0 $\mathrm{h}$ time point (Fig. 3B).

With both comparative bioinformatic analysis and expression pattern supporting our hypothesis that $\operatorname{Cebp} \beta$ could regulate Lepr expression, we used ChIP-qPCR assay to test if Cebp $\beta$ is recruited to the Lepr promoter in granulosa cells. We chose $2 \mathrm{~h}$ post-hCG time point based on the maximal Lepr expression in granulosa cells (Fig. 1A and B). As shown in Fig. 3C, immunoprecipitation of granulosa cell chromatin using Cebp $\beta$ antibody showed significant enrichment of the Lepr promoter region containing putative Cebp-binding sites as compared with normal rabbit IgG control. Furthermore, there was no enrichment of the $5^{\prime}$-UTR of Myod1 gene, which does not contain a Cebp $\beta$ binding site (Fig. 3C).

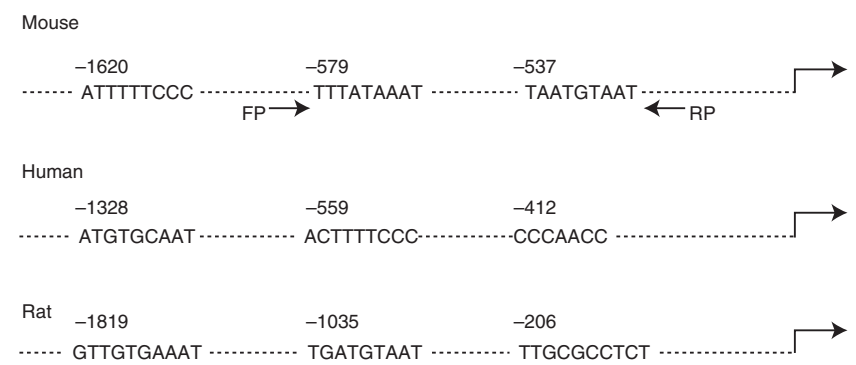

Figure 2 A comparative bioinformatics analysis of the proximal promoter of mouse, human and rat $\operatorname{Cebp} \beta$. The promoter sequences were obtained from the UCSC Genome Browser. Multiple potential binding sites for Cebp $\beta$ in the promoter sequence of each species were identified using the online Patch Software. Sequences of each identified Cebp $\beta$ element and their respective distance from the transcription start site (arrow) are shown. FP and RP, positions of the forward and reverse primers used to amplify the Cebp $\beta$-element-containing region following ChIP assay are also shown on the mouse promoter. 


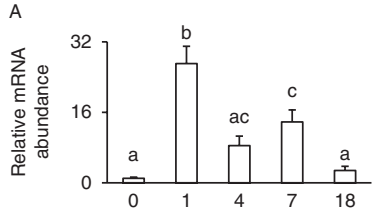

Time after hCG administration (h)
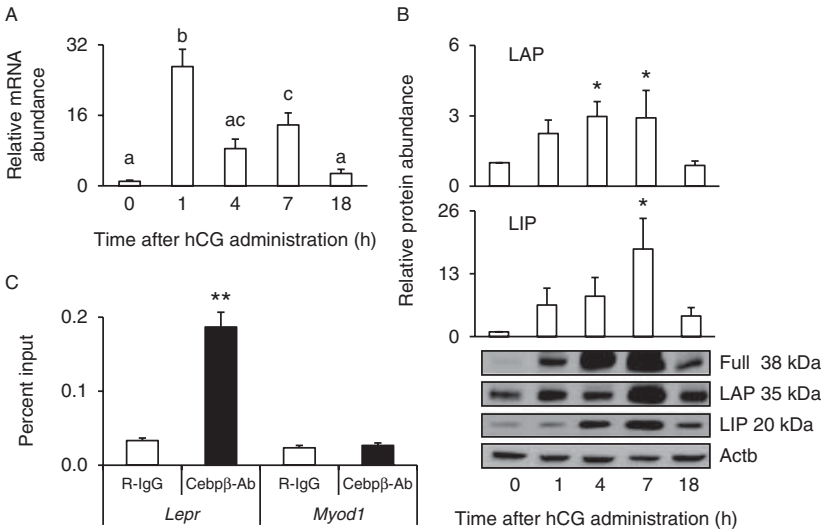

Figure 3 Cebp $\beta$ regulates Lepr expression in granulosa cells. (A) Relative mRNA expression pattern of Cebp $\beta$ during follicular and luteal development in granulosa and luteal cells of superovulated mice ( $n=3-5$ per time point). Different letters indicate a significant difference $(P<0.05)$. (B) Protein abundance of the full-length, LAP and LIP isoforms of CEBP $\beta$ in granulosa and luteal cells of superovulated mice. Actb was used as loading control. Protein abundance was quantified for LAP and LIP isoforms, relative to hCG $0 \mathrm{~h}$ within each of the five different sets of immunoblots. ${ }^{*} A$ significant difference from hCG 0 h time point $(P<0.05)$. (C) Chromatin immunoprecipitation (ChIP) using granulosa cells of superovulated mice collected at $4 \mathrm{~h}$ post-hCG. Anti-Cebp $\beta$ antibody was used for ChIP analysis and normal rabbit IgG as control. The precipitated chromatin was analysed by qPCR using the primers designed to amplify a putative Cebp $\beta$-element containing Lepr promoter. A proximal promoter region of Myod1 that does not contain any Cebp $\beta$ element was used as a non-Cebp $\beta$-specific target. Data are expressed as mean \pm S.E.M. from three different ChIP analyses. ${ }^{* *}$ A significant difference $(P<0.05)$.

These data confirm that $\operatorname{Cebp} \beta$ is recruited to the Lepr promoter during the time of its peak mRNA abundance in the granulosa cells of ovulating follicles.

\section{Inhibition of Lepr signalling results in reduced ovulation}

Based on the expression pattern of Lepr and its induction by hCG through $\operatorname{Cebp} \beta$, we hypothesised that Lepr may be necessary for normal ovulation. To test this hypothesis, we used a recently developed Lepr antagonist, PEG-SMLA, to inhibit Lepr signalling during hCGstimulated ovulation in superstimulated mice. The number of oocytes ovulated in oviducts collected at $18-20 \mathrm{~h}$ post-hCG in inhibitor-treated mice was decreased by $65 \%$ as compared with PBS-treated mice $(P<0.05$; Fig. 4A). Microscopic analyses showed that the oocytes of both PBS and PEG-SMLA-treated mice were in metaphase II stage (Fig. 4B).

\section{Effect of PEG-SMLA on granulosa gene expression}

In order to determine the molecular basis for reduced ovulation in PEG-SMLA-treated mice, we collected granulosa cells at $4 \mathrm{~h}$ post-hCG from mice treated with PEG-SMLA or PBS. This time point was chosen to investigate molecular perturbations caused by inhibition of Lepr signalling at its peak expression. Relative levels of hyaluronan synthase 2 (Has2) and Ptgs2 were significantly decreased in granulosa cells of PEG-SMLAtreated mice as compared with those of PBS-treated animals $(P<0.05$; Fig. 5B).

\section{Discussion}

In this study, we showed that Lepr gene expression is dramatically induced at $4 \mathrm{~h}$ post-hCG in the granulosa cells of ovulating follicles. The increased mRNA expression of LeprA and LeprB isoforms in granulosa cells at $4 \mathrm{~h}$ post-hCG is in agreement with their increased expression at $9 \mathrm{~h}$ post-hCG in rat ovaries (Ryan et al. 2003). The pattern observed in the rat study using the whole ovary may therefore be a result of Lepr gene expression in granulosa cells. We also found that mRNA abundance of Lep was modestly but significantly induced by hCG, which is also in agreement with a previous study on rats (Ryan et al. 2003). Overall, these data on Lepr and Lep expression in granulosa cells suggest that leptin signalling is enhanced within the microenvironment of ovulating follicles in mice.
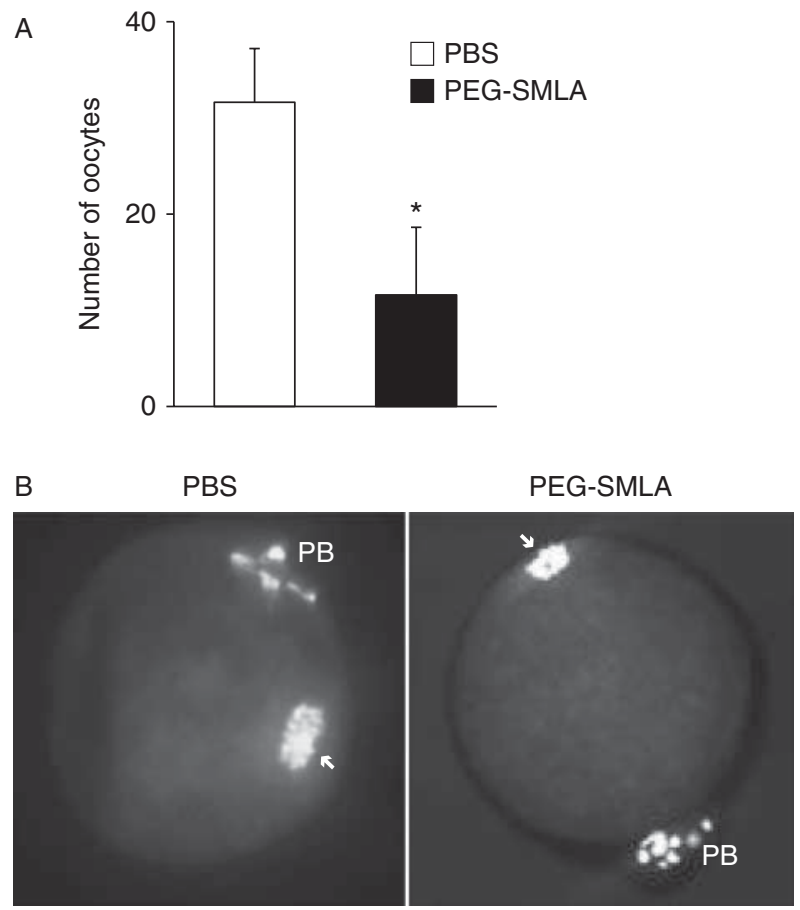

Figure 4 PEG-SMLA treatment decreases ovulation rate in superovulated mice. (A) Ovulation rate was determined by counting oocytes in the oviducts collected at $18 \mathrm{~h}$ post-hCG from superovulated mice administered with $10 \mu \mathrm{g} / \mathrm{g}(n=5)$ PEG-SMLA or PBS at $0 \mathrm{~h}$ hCG $(n=11)$. Data are expressed as mean \pm s.E.M. ${ }^{*}$ A significant difference $(P<0.05)$. (B) Maturation status is unaltered in the oocytes of PEG-SMLA-treated animals. DNA from ovulated oocytes was stained with Hoechst stain and observed under fluorescence. Arrow indicates condensed chromatin of the oocyte and PB indicates degrading polar body. 

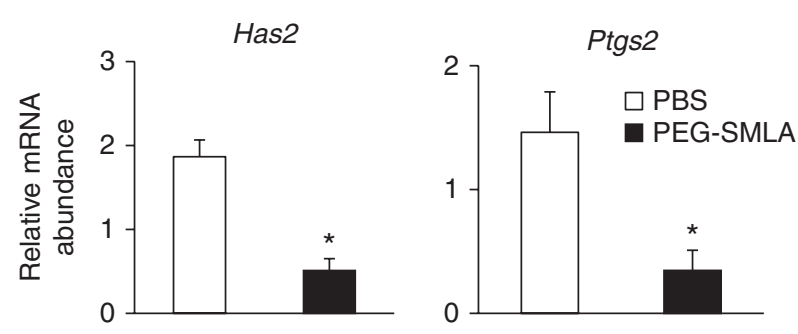

Figure 5 Inhibition of Lepr signalling using PEG-SMLA reduces mRNA expression of ovulation genes. Real-time PCR analysis of the mRNA abundance of Has2 and Ptgs 2 in granulosa cells of superovulated PEGSMLA/PBS treated mice at $4 \mathrm{~h}$ post-hCG. PEG-SMLA $(10 \mu \mathrm{g} / \mathrm{g})$ or PBS was administered at $0 \mathrm{~h}$ post-hCG and granulosa cells were collected by follicle puncture at $4 \mathrm{~h}$ post-hCG. Data are expressed as mean \pm S.E.M. $\left(n=3-4\right.$ per group). ${ }^{*}$ A significant difference $(P<0.05)$.

The data of this study also indicate that LeprA mRNA abundance is higher than LeprB the in granulosa cells of ovulating follicles. Although not many of the ovarian/ granulosa cell studies consider both LeprA and LeprB isoforms, Ryan et al. (2003) showed that the LeprA (Ob-Ra) isoform was slightly higher as compared with the LeprB (Ob-Rb) isoform in rat ovaries. The bigger difference between the two isoforms in our study could be due to purified populations of granulosa. In fact, LeprA mRNA abundance has been shown to be dramatically higher than $L$ eprB mRNA in multiple nonhypothalamic tissues including the ovary, uterus and pituitary in cattle (Thorn et al. 2007). Similarly, several other studies in mice have shown that LeprA is highly expressed with very minimal expression of LeprB in all tissues except the hypothalamus (Ghilardi et al. 1996, Fei et al. 1997, Chen et al. 1999). Thus, our data suggest that LeprA may have a predominant role in granulosa cells, especially during the periovulatory period.

Our data along with others (Duggal et al. 2002, Ryan et al. 2003) clearly demonstrate that Lepr gene expression is induced in granulosa cells of ovulating follicles. Thus, it is very interesting to study the mechanisms of transcriptional regulation of Lepr in granulosa cells of ovulating follicles. Our hypothesis was that $\operatorname{Cebp} \beta$ could be one of the transcription factors regulating Lepr expression. This hypothesis was based on the reports that overexpression of Cebp $\beta$ the in Hep3B cells increased Lepr expression (Saint-Auret et al. 2011) and conditional deletion of Cebp $\alpha / \beta$ in granulosa cells abrogated hCG-induced expression of Lepr (Fan et al. 2011). Indeed, we found that $C е b p \beta$ was significantly induced at $1 \mathrm{~h}$ post-hCG, before Lepr induction at $4 \mathrm{~h}$ post-hCG, and comparative bioinformatic analyses predicted multiple Cebp $\beta$ binding sites on the Lepr promoter for the rat, human and mouse. Presence of the $\operatorname{Cebp} \beta$ binding site in three species indicates that Cebp $\beta$-driven regulation of Lepr is a well-conserved mechanism. Confirming our hypothesis, ChIP analysis using the chromatin from granulosa cells of ovulating follicles provides strong evidence for $\operatorname{Cebp} \beta$ binding to the Lepr promoter during its peak expression. Therefore, the data in this study indicate that leptin signalling could be one of the pathways that $\operatorname{Cebp} \beta$ regulates in granulosa cells of ovulating follicles and thereby ovulation (Sterneck et al. 1997).

Intriguingly, our immunoblot analyses showed that protein abundance of LAP isoform was significantly higher at 4 and $7 \mathrm{~h}$ post-hCG and LIP isoform at $7 \mathrm{~h}$ posthCG compared with hCG-0 $\mathrm{h}$ time point. These isoforms are generated by alternative translation start sites (Calkhoven et al. 2000), and LAP and LIP isoforms are shown to have opposing transcriptional activity (Descombes \& Schibler 1991). Overexpression of the LAP isoform activated Lepr expression and overexpression of LIP isoform inhibited Lepr expression in cultured Hep3B cells (Saint-Auret et al. 2011). In light of these results and our ChIPanalysis, it is plausible that the LAP isoform of Cebp $\beta$ induces Lepr expression by $4 \mathrm{~h}$ post-hCG and the LIP isoform inhibits its expression by $7 \mathrm{~h}$ post-hCG. Unfortunately, it was impossible for us to test this hypothesis using ChIP assay as there is no commercially available ChIP-grade and isoform-specific antibody against $\operatorname{Cebp} \beta$. The one used in this study identifies both LAP and LIP isoforms.

Dramatic induction of Lepr isoforms by preovulatory hCG through Cebp $\beta$ and the importance of $\operatorname{Cebp} \beta$ in ovulation (Sterneck et al. 1997, Fan et al. 2011) led us to hypothesise that Lepr could be essential for ovulation. The role of leptin in ovulation is still unresolved because of contrasting evidence with both reduced ovulation rate (Duggal et al. 2000, Ricci et al. 2006) and increased ovulation rate (Almog et al. 2001) in leptin-treated rats. Therefore, we took a complementary loss-of-function approach to inhibit Lepr signalling in the ovary. We used a recently developed leptin antagonist (Shpilman et al. 2011) to antagonise leptin action in vivo in immature mice during the superstimulation protocol. Administration of PEG-SMLA has been shown to increase body weight in $\alpha$ MUPA mice, which are otherwise resistant to obesity due to high leptin concentrations (Chapnik et al. 2013). Therefore, the PEG-SMLA was ideal for our in vivo model. The antagonist at a dose of $10 \mu \mathrm{g} / \mathrm{g}$, administered at hCG stimulation, significantly reduced ovulation rate in immature superovulated animals. Previously, similar doses were found to induce a more significant increase in weight gain in mice (Shpilman et al. 2011).

Although ovulation rate was decreased by over $65 \%$, meiotic maturation of the ovulated oocytes was unaltered as evidenced by a similar number of oocytes in metaphase II stage in PBS and PEG-SMLA-treated mice. However, leptin treatment of bovine oocytes in vitro $(1-10 \mathrm{ng} / \mathrm{ml})$ increased the rate of development in metaphase II (Paula-Lopes et al. 2007, Jia et al. 2012). Leptin treatment was found to increase the rate of meiotic resumption in the murine ovary (Barash et al. 1996, Ryan et al. 2002). In our study, inhibition of Lepr 
using PEG-SMLA impaired only follicle rupture without affecting meiotic maturation of oocytes. While we are unable to explain the reason for the lack of effect of PEGSMLA on meiosis, these data warrant further in vitro analysis of oocyte maturation using PEG-SMLA.

Though leptin has previously been shown to affect the ovulation process both negatively and positively (Almog et al. 2001, Ricci et al. 2006), through its actions at the ovarian level, the molecular mechanisms have never been explored. In light of the peak expression of LeprA and LeprB at $4 \mathrm{~h}$ post-hCG, which is a very important time point for the expression of ovulation-related genes, we hypothesised that Lepr may play an important role in hCG (LH)-driven gene expression. Indeed, our data show that PEG-SMLA treatment at the time of hCG stimulation resulted in reduced expression of Ptgs2 and Has2. It is very well established that both Ptgs2 and Has2 play indispensable roles in terminal differentiation of granulosa cells of the ovulating follicle (Duggavathi \& Murphy 2009, Richards \& Pangas 2010). In line with our data, a previous in vivo study showed that leptin induces Ptgs2 expression in the rat brain (Inoue et al. 2006). Also several in vitro studies have shown that leptin increases Ptgs2 expression in endothelial cells (Manuel-Apolinar et al. 2013), renal tubular cells (Hsu et al. 2012) and endometrial cells (Gao et al. 2009). Notwithstanding this, other studies have shown either no effect (Wazir et al. 2012) or inhibition (Tsai et al. 2006) of Ptgs2 expression in response to leptin treatment. These studies show that when the role of leptin signalling is examined using leptin-treatment approach, the results appear to depend on the dose of leptin used. Indeed it has been shown that high-dose acute treatment with leptin inhibits (Duggal et al. 2000), while low-dose chronic treatment enhances (Almog et al. 2001) ovulation rate in rats. Therefore, at basal levels of leptin, Lepr may positively regulate hCG-induced expression of Ptgs2. Further support for Lepr regulation of Has2 comes from a study (van Tol et al. 2010) that showed a positive correlation between Lepr and cumulus expansion genes HAS2 and PTX3 in human cumulus cells. Taken together, our data suggest that Lepr plays an important role in $\mathrm{LH}$-induced ovulatory process, at least in part, through regulation of Ptgs2 and Has2.

Overall, the data in this study contribute to our further understanding of leptin regulation of ovarian function. Ovaries of the $d b / d b$ mouse, which expresses all isoforms except LeprB, are normal (Bahary et al. 1990), demonstrating that direct actions of leptin on the ovary may involve other isoforms of Lepr. This inference is further supported by the fact that neuron-specific replacement of LeprB rescues fertility in $d b / d b$ mice lacking only LeprB (de Luca et al. 2005) but not in $d b^{3 \mathrm{j}} / d b^{3 \mathrm{j}}$ mice lacking all Lepr isoforms in all tissues including the ovary (Kowalski et al. 2001). In light of these reports, our data indicating a more drastic increase in expression of the LeprA isoform in granulosa cells and disruption of normal ovulation due to leptin antagonist treatment suggest that LeprA isoform may be more important for the regulation of ovulation by leptin signalling. While our pharmacological approach revealed the potential role of leptin signalling in ovulation, additional studies are needed for further understanding.

\section{Declaration of interest}

The authors declare that there is no conflict of interest that could be perceived as prejudicing the impartiality of the research reported.

\section{Funding}

This research was supported by funds from NSERC (Rgpin 371850-09), FQRNT (2011-NC-137832) and McGill-CSR (seed grant) to R Duggavathi. CSR graduate student fellowship for L Dupuis and RQR scholarship for $Y$ Schuermann, A Kalaiselvanraja and D Siddappa.

\section{Acknowledgements}

The authors thank Dr Silvana Obici (University of Cincinnati) for donating LeprB primers and Dr Timothy Keiffer (University of British Columbia) for help with procurement of PEG-SMLA.

\section{References}

Accili D, Drago J, Lee EJ, Johnson MD, Cool MH, Salvatore P, Asico LD, Jose PA, Taylor SI \& Westphal H 1996 Early neonatal death in mice homozygous for a null allele of the insulin receptor gene. Nature Genetics 12 106-109. (doi:10.1038/ng0196-106)

Almog B, Gold R, Tajima K, Dantes A, Salim K, Rubinstein M, Barkan D, Homburg R, Lessing JB, Nevo N et al. 2001 Leptin attenuates follicular apoptosis and accelerates the onset of puberty in immature rats. Molecular and Cellular Endocrinology 183 179-191. (doi:10.1016/ S0303-7207(01)00543-3)

Bahary N, Leibel RL, Joseph L \& Friedman JM 1990 Molecular mapping of the mouse db mutation. PNAS 87 8642-8646. (doi:10.1073/pnas.87. 21.8642)

Barash IA, Cheung CC, Weigle DS, Ren H, Kabigting EB, Kuijper JL, Clifton DK \& Steiner RA 1996 Leptin is a metabolic signal to the reproductive system. Endocrinology 137 3144-3147. (doi:10.1210/ en.137.7.3144)

Baumann H, Morella KK, White DW, Dembski M, Bailon PS, Kim H, Lai CF \& Tartaglia LA 1996 The full-length leptin receptor has signaling capabilities of interleukin 6-type cytokine receptors. PNAS 93 8374-8378. (doi:10.1073/pnas.93.16.8374)

Bustin SA, Benes V, Garson JA, Hellemans J, Huggett J, Kubista M, Mueller R, Nolan T, Pfaffl MW, Shipley GL et al. 2009 The MIQE guidelines: minimum information for publication of quantitative realtime PCR experiments. Clinical Chemistry 55 611-622. (doi:10.1373/ clinchem.2008.112797)

Calkhoven CF, Muller C \& Leutz A 2000 Translational control of C/EBP $\alpha$ and C/EBP $\beta$ isoform expression. Genes and Development 14 1920-1932.

Chapnik N, Solomon G, Genzer Y, Miskin R, Gertler A \& Froy O 2013 A superactive leptin antagonist alters metabolism and locomotion in high-leptin mice. Journal of Endocrinology 217 283-290. (doi:10.1530/ JOE-13-0033) 
Chen SC, Kochan JP, Campfield LA, Burn P \& Smeyne RJ 1999 Splice variants of the $\mathrm{OB}$ receptor gene are differentially expressed in brain and peripheral tissues of mice. Journal of Receptors and Signal Transduction Research 19 245-266. (doi:10.3109/10799899909036649)

Cottrell EC \& Mercer JG 2012 Leptin receptors. Handbook of Experimental Pharmacology 209 3-21. (doi:10.1007/978-3-642-24716-3_1)

Descombes P \& Schibler U 1991 A liver-enriched transcriptional activator protein, LAP, and a transcriptional inhibitory protein, LIP, are translated from the same mRNA. Cell 67 569-579. (doi:10.1016/00928674(91)90531-3)

Di Yorio MP, Bilbao MG, Biagini-Majorel AM \& Faletti AG 2013 Ovarian signalling pathways regulated by leptin during the ovulatory process. Reproduction 146 647-658. (doi:10.1530/REP-13-0257)

Duggal PS, Van Der Hoek KH, Milner CR, Ryan NK, Armstrong DT, Magoffin DA \& Norman RJ 2000 The in vivo and in vitro effects of exogenous leptin on ovulation in the rat. Endocrinology 141 1971-1976. (doi:10.1210/en.141.6.1971)

Duggal PS, Weitsman SR, Magoffin DA \& Norman RJ 2002 Expression of the long (OB-RB) and short (OB-RA) forms of the leptin receptor throughout the oestrous cycle in the mature rat ovary. Reproduction 123 899-905. (doi:10.1530/rep.0.1230899)

Duggavathi R \& Murphy BD 2009 Development. Ovulation signals. Science 324 890-891. (doi:10.1126/science.1174130)

Duggavathi R, Volle DH, Mataki C, Antal MC, Messaddeq N, Auwerx J, Murphy BD \& Schoonjans K 2008 Liver receptor homolog 1 is essential for ovulation. Genes and Development 22 1871-1876. (doi:10.1101/ gad.472008)

Fan HY, Liu Z, Johnson PF \& Richards JS 2011 CCAAT/enhancer-binding proteins $(C / E B P)-\{\alpha\}$ and $-\{\beta\}$ are essential for ovulation, luteinization, and the expression of key target genes. Molecular Endocrinology 25 253-268. (doi:10.1210/me.2010-0318)

Fei H, Okano HJ, Li C, Lee GH, Zhao C, Darnell R \& Friedman JM 1997 Anatomic localization of alternatively spliced leptin receptors (Ob-R) in mouse brain and other tissues. PNAS 94 7001-7005. (doi:10.1073/pnas. 94.13.7001)

Gao J, Tian J, Lv Y, Shi F, Kong F, Shi H \& Zhao L 2009 Leptin induces functional activation of cyclooxygenase-2 through JAK2/ STAT3, MAPK/ERK, and PI3K/AKT pathways in human endometrial cancer cells. Cancer Science 100 389-395. (doi:10.1111/j.1349-7006. 2008.01053.x)

Ghilardi N, Ziegler S, Wiestner A, Stoffel R, Heim MH \& Skoda RC 1996 Defective STAT signaling by the leptin receptor in diabetic mice. PNAS 93 6231-6235. (doi:10.1073/pnas.93.13.6231)

Hsu YH, Cheng CY, Chen YC, Chen TH, Sue YM, Tsai WL \& Chen CH 2012 Long-term leptin treatment exerts a pro-apoptotic effect on renal tubular cells via prostaglandin $\mathrm{E}_{2}$ augmentation. European Journal of Pharmacology 689 65-71. (doi:10.1016/j.ejphar.2012.06.008)

Inoue W, Poole S, Bristow AF \& Luheshi GN 2006 Leptin induces cyclooxygenase- 2 via an interaction with interleukin- $1 \beta$ in the rat brain. European Journal of Neuroscience 24 2233-2245. (doi:10.1111/j.14609568.2006.05105.x)

Jia Z, Zhang J, Wu Z \& Tian J 2012 Leptin enhances maturation and development of calf oocytes in vitro. Reproduction in Domestic Animals 47 718-723. (doi:10.1111/j.1439-0531.2011.01949.x)

Karlsson C, Lindell K, Svensson E, Bergh C, Lind P, Billig H, Carlsson LM \& Carlsson B 1997 Expression of functional leptin receptors in the human ovary. Journal of Clinical Endocrinology and Metabolism 82 4144-4148. (doi:10.1210/jc.82.12.4144)

Kowalski TJ, Liu SM, Leibel RL \& Chua SC Jr 2001 Transgenic complementation of leptin-receptor deficiency. I. Rescue of the obesity/ diabetes phenotype of LEPR-null mice expressing a LEPR-B transgene. Diabetes 50 425-435. (doi:10.2337/diabetes.50.2.425)

Lee GH, Proenca R, Montez JM, Carroll KM, Darvishzadeh JG, Lee JI \& Friedman JM 1996 Abnormal splicing of the leptin receptor in diabetic mice. Nature 379 632-635. (doi:10.1038/379632a0)

de Luca C, Kowalski TJ, Zhang Y, Elmquist JK, Lee C, Kilimann MW, Ludwig T, Liu SM \& Chua SC Jr 2005 Complete rescue of obesity, diabetes, and infertility in $\mathrm{db} / \mathrm{db}$ mice by neuron-specific LEPR-B transgenes. Journal of Clinical Investigation 115 3484-3493. (doi:10. $1172 / \mathrm{JCl} 24059)$
Lydon JP, DeMayo FJ, Funk CR, Mani SK, Hughes AR, Montgomery CA Jr, Shyamala G, Conneely OM \& O'Malley BW 1995 Mice lacking progesterone receptor exhibit pleiotropic reproductive abnormalities. Genes and Development 9 2266-2278. (doi:10.1101/gad.9.18.2266)

Mandelbaum J 2000 Oocytes. Human Reproduction 15 (Suppl 4) 11-18. (doi:10.1093/humrep/15.suppl_4.11)

Manuel-Apolinar L, Lopez-Romero R, Zarate A, Damasio L, Ruiz M, Castillo-Hernandez C, Guevara G \& Mera-Jimenez E 2013 Leptin mediated $\mathrm{ObRb}$ receptor increases expression of adhesion intercellular molecules and cyclooxygenase 2 on murine aorta tissue inducing endothelial dysfunction. International Journal of Clinical and Experimental Medicine 6 192-196.

Murakami T, Yamashita T, lida M, Kuwajima M \& Shima K 1997 A short form of leptin receptor performs signal transduction. Biochemical and Biophysical Research Communications 231 26-29. (doi:10.1006/bbrc. 1996.6030)

Paula-Lopes FF, Boelhauve M, Habermann FA, Sinowatz F \& Wolf E 2007 Leptin promotes meiotic progression and developmental capacity of bovine oocytes via cumulus cell-independent and -dependent mechanisms. Biology of Reproduction 76 532-541. (doi:10.1095/ biolreprod.106.054551)

Ricci AG, Di Yorio MP \& Faletti AG 2006 Inhibitory effect of leptin on the rat ovary during the ovulatory process. Reproduction 132 771-780. (doi:10.1530/rep.1.01164)

Richards JS \& Pangas SA 2010 The ovary: basic biology and clinical implications. Journal of Clinical Investigation 120 963-972. (doi:10. 1172/JCl41350)

Ruiz-Cortes ZT, Martel-Kennes Y, Gevry NY, Downey BR, Palin M-F \& Murphy BD 2003 Biphasic effects of leptin in porcine granulosa cells. Biology of Reproduction 68 789-796. (doi:10.1095/biolreprod.102. 010702)

Ryan NK, Woodhouse CM, Van der Hoek KH, Gilchrist RB, Armstrong DT \& Norman RJ 2002 Expression of leptin and its receptor in the murine ovary: possible role in the regulation of oocyte maturation. Biology of Reproduction 66 1548-1554. (doi:10.1095/biolreprod66.5.1548)

Ryan NK, Van der Hoek KH, Robertson SA \& Norman RJ 2003 Leptin and leptin receptor expression in the rat ovary. Endocrinology 144 5006-5013. (doi:10.1210/en.2003-0584)

Saint-Auret G, Danan JL, Hiron M, Blache C, Sulpice E, Tendil S, Daveau M, Gidrol X \& Salier JP 2011 Characterization of the transcriptional signature of C/EBP $\beta$ isoforms (LAP/LIP) in Hep3B cells: implication of LIP in pro-survival functions. Journal of Hepatology $\mathbf{5 4}$ 1185-1194. (doi:10.1016/j.jhep.2010.09.021)

Shpilman M, Niv-Spector L, Katz M, Varol C, Solomon G, Ayalon-Soffer M, Boder E, Halpern Z, Elinav E \& Gertler A 2011 Development and characterization of high affinity leptins and leptin antagonists. Journal of Biological Chemistry 286 4429-4442. (doi:10.1074/jbc.M110.196402)

Sirotkin AV, Rafay J \& Kotwica J 2009 Leptin controls rabbit ovarian function in vivo and in vitro: possible interrelationships with ghrelin. Theriogenology 72 765-772. (doi:10.1016/j.theriogenology.2009.05.011)

Spicer LJ 2001 Leptin: a possible metabolic signal affecting reproduction. Domestic Animal Endocrinology 21 251-270. (doi:10.1016/S07397240(01)00120-5)

Spicer LJ \& Francisco CC 1997 The adipose obese gene product, leptin: evidence of a direct inhibitory role in ovarian function. Endocrinology 138 3374-3379. (doi:10.1210/en.138.8.3374)

Sterneck E, Tessarollo L \& Johnson PF 1997 An essential role for C/EBP $\beta$ in female reproduction. Genes and Development 11 2153-2162. (doi:10.1101/gad.11.17.2153)

Svotelis A, Bianco S, Madore J, Huppe G, Nordell-Markovits A, Mes-Masson AM \& Gevry N 2011 H3K27 demethylation by JMJD3 at a poised enhancer of anti-apoptotic gene BCL2 determines ER $\alpha$ ligand dependency. EMBO Journal 30 3947-3961. (doi:10.1038/emboj. 2011.284)

Thorn SR, Meyer MJ, Van Amburgh ME \& Boisclair YR 2007 Effect of estrogen on leptin and expression of leptin receptor transcripts in prepubertal dairy heifers. Journal of Dairy Science 90 3742-3750. (doi:10.3168/jds.2007-0009)

van Tol HT, Vernooij JC, Colenbrander B, Gutknecht D, Macklon NS \& Roelen BA 2010 Expression of leptin receptor mRNA in cumulus cells is correlated with expression of PTX3. Reproductive Biomedicine Online 20 741-750. (doi:10.1016/j.rbmo.2010.03.003) 
Tsai EM, Chan TF, Chang Y, Chiang PH, Chuang CY, Long CY, Chai CY \& Lee JN 2006 Leptin suppresses human chorionic gonadotropininduced cyclooxygenase-2 expression and prostaglandin production in cultured human granulose luteal cells. Journal of the Society for Gynecologic Investigation 13 551-557. (doi:10.1016/j.jsgi.2006. 09.004)

Wauters M, Considine RV \& Van Gaal LF 2000 Human leptin: from an adipocyte hormone to an endocrine mediator. European Journal of Endocrinology 143 293-311. (doi:10.1530/eje.0.1430293)

Wazir U, Al Sarakbi W, Jiang WG \& Mokbel K 2012 Evidence of an autocrine role for leptin and leptin receptor in human breast cancer. Cancer Genomics \& Proteomics 9 383-387.
Zachow RJ \& Magoffin DA 1997 Direct intraovarian effects of leptin: impairment of the synergistic action of insulin-like growth factor-I on follicle-stimulating hormone-dependent estradiol- $17 \beta$ production by rat ovarian granulosa cells. Endocrinology 138 847-850. (doi:10.1210/ en.138.2.847)

Received 3 August 2013

First decision 28 August 2013

Revised manuscript received 12 November 2013

Accepted 20 November 2013 